\title{
Electromagnetic Wave Irradiation Promotes Osteoblastic Cell Proliferation and Up-Regulates Growth Factors via Activation of the ERK1/2 and p38 MAPK Pathways
}

\author{
Hiromichi Yumoto Kouji Hirao Toshihiko Tominaga Naoki Bando \\ Kanako Takahashi Takashi Matsuo \\ Department of Conservative Dentistry, Institute of Health Biosciences, The University of Tokushima \\ Graduate School, Tokushima, Japan
}

\section{Key Words}

Electromagnetic Wave Irradiation • Osteoblasts $•$ Cell proliferation $\bullet$ Growth factors $•$ Signaling

\begin{abstract}
Background/Aims: Periodontitis with bone resorption is caused by inflammatory reactions to bacterial infection. We recently reported that electromagnetic wave irradiation (EMWI) has bactericidal effects. However, the effects of EMWI on periodontal tissues remain unclear. This study was aimed to investigate the effects of EMWI on osteoblasts. Methods: Osteoblastic cells MC3T3-E1 were treated with EMWI $(500-1,000 \mathrm{kHz}, 5$ times, $1 \mathrm{sec} / \mathrm{time})$. Cell growth and cytotoxicity were determined by cell proliferation assays and measurement of lactate dehydrogenase release, respectively. Gene expression and protein production of growth factors were analyzed using real-time PCR and ELISA, respectively. EMWI-activated cellular signal transduction pathways were investigated by immunoblotting and blocking assay with specific inhibitors. Results: Osteoblasts proliferation was significantly enhanced 3 days after EMWI and no cytotoxicity was observed. EMWI up-regulated various growth factors, such as vascular endothelial growth factor (VEGF) and platelet-derived growth factor (PDGF). EMWI induced ERK1/2, p38 MAPK and SAPK/JNK phosphorylation within $5 \mathrm{~min}$, and the production of PDGF-AA and VEGF was partially reduced by MAPK-specific inhibitor. Conclusion: These findings demonstrated that EMWI increases osteoblastic cell activity and the expression of growth factors via ERK1/2 and p38 MAPK pathways and suggested that EMWI may be beneficial to bone tissue repair such as periodontitis.
\end{abstract}

Copyright $(2015$ S. Karger AG, Basel

Hiromichi Yumoto

KARGER 125
Department of Conservative Dentistry, Institute of Health Biosciences,

The University of Tokushima Graduate School, 3-18-15 Kuramoto-cho,

Tokushima, Tokushima, 770-8504 (Japan)

Tel. +81 88633 7340, Fax +81 88633 9127, E-Mail yumoto@tokushima-u.ac.jp 


\section{Introduction}

Periodontal diseases are highly prevalent and affect up to $90 \%$ of the worldwide population [1]. In addition to their high prevalence, these diseases are associated with serious public concerns, because periodontal diseases have been linked with various systemic diseases including cardiovascular disease, stroke, pulmonary disease, diabetes and adverse pregnancy outcomes. Periapical and marginal periodontitis are inflammatory disorders of peri-radicular and periodontal tissues caused by persistent microbial biofilms formed in the root canal system and periodontal pocket, respectively, which lead to destruction of supporting tissues of the tooth and finally to tooth loss [2-6]. Therefore, complete removal of bacteria and all causal agents within the root canal system and periodontal pocket by debridement is important for the prevention and treatment for periapical and marginal periodontitis. Another important point in the treatment of periodontitis is to promote wound healing of bony defects and surrounding tissues and to increase new bone formation as part of periodontal regenerative therapy.

Non-surgical treatment of periapical and marginal periodontitis has traditionally been accompanied with hand instruments, ultrasonic devices or local medications to remove bacterial deposits and infected tissues and to inactivate pathogenic bacteria. However, no consensus has been reached on whether ultrasonic treatment and mechanical removal with hand instruments can eliminate all pathogens present in infected sites [7]. Recently, laser therapy, such as with high-level erbium:yttrium-aluminium-garnet (Er:YAG) and neodymium:yttrium- aluminium-garnet (Nd:YAG) lasers, has been introduced in periodontal therapy, because dental lasers display several advantages that may be valuable in managing periodontal disease in addition to their anti-inflammatory effects [8-15]. Previous studies have reported that Er:YAG laser irradiation has beneficial effects, including calculus removal, high bactericidal effect, and potential biostimulation [16-21] and lower pulse energy Nd:YAG laser irradiation resulted in effective in eradication of both aerobic and anaerobic microorganisms as well as in neutralizing pro-inflammatory molecules such as lipopolysaccharide [22-24]. In recent years, in vitro and in vivo studies have reported that photodynamic therapy, combining low-energy laser light with photosensitizing compounds that bind to target cells, is useful for eradicating bacteria from periodontal pockets $[23,25$ 27]. However, the antimicrobial effects of laser irradiation are inversely proportional to the square of the distance from the light source to the target area. Several major problems have been pointed out with regard to laser irradiation. Laser light only travels in a straight line and does not reach the apical root portion through the curved root canal. It is also impossible to insert the light source tip near the apical root portion because of the narrow, curved root canal. Therefore, it remains necessary to improve the sharpness and material of laser tips for application in complex regions. So far, laser irradiation therapy for periapical and marginal periodontitis still has clinical limitations.

Recently, we reported that electromagnetic wave irradiation (EMWI) has inactivation and bactericidal activities against oral pathogens and suggested that EMWI has several advantages, such as rapid heating, pathogen destruction and inactivation, ease of control and compactness, over previously developed treatments. As such, EMWI may be applicable for medical disinfection and sterilization, such as in refractory periapical periodontitis [28]. In addition, using a thin, flexible instrument (K-file No. 10), which has suitable mechanical strength compared with smaller files (No. 6 and 8) as an active electrode, EMWI may be applicable to small, narrow, curved or complex morphological regions infected with bacteria. Therefore, EMWI has advantages over laser irradiation systems.

It has been reported that physical stresses, such as electrical stimulation and mechanical loading, promote osteogenesis and healing in bone fractures [29]. Since the discovery of the natural electrical properties of bone, the concept of electric current has been introduced as an important tool in bone remodeling, and various kinds of electrical stimulations have been investigated for their effects on bone regeneration [30]. Pulsed electromagnetic fields exert stimulating effects on the proliferation of osteoblasts and the production of cytokines, such 
as transforming growth factor (TGF)- $\beta 1$ [31-33]. However, the effect of pulsed EMWI on osteoblasts has not yet been investigated. In this study, we investigated the activating effects of EMWI on osteoblastic cells to evaluate the potential application of EMWI to enhance the healing of periodontal lesions.

\section{Materials and Methods}

\section{Osteoblastic cell line culture}

The osteoblastic cell line MC3T3-E1 (European Collection of Cell Cultures, Salisbury, UK) established from mouse C57BL/6 calvaria was cultured in $\alpha \mathrm{MEM}$ medium supplemented with $10 \%$ (vol/vol) fetal bovine serum (JRH Biosciences, Lenexa, KS, USA), 2 mM glutamine, $100 \mu \mathrm{g} / \mathrm{ml}$ streptomycin, and 100 units/ $\mathrm{ml}$ penicillin in $5 \% \mathrm{CO}_{2}$ at $37^{\circ} \mathrm{C}$.

\section{Electromagnetic wave (EMW) source and irradiation}

Electromagnetic waves (EMWs) were generated using high-frequency therapy equipment (J. MORITA MFG. Corp., Kyoto, Japan) [28]. The frequency of EMWs from this treatment device was set to $500-1,000 \mathrm{kHz}$ and $228 \mathrm{~V}$, and tone-burst waves with a large crest factor were employed to efficiently generate arch discharges. An endodontic hand-operated instrument (K-file No. 10; MANI, Inc., Utsunomiya, Japan) as an active electrode tip was inserted $1 \mathrm{~mm}$ from the culture fluid surface and the current was passed intermittently for $1 \mathrm{sec} /$ time at intervals of 2 seconds. The temperature of the cell culture medium during EMWI was monitored using a thermometer (CUSTUM CT-1300 Type K; CUSTUM, Tokyo, Japan).

\section{Cell proliferation analysis}

MC3T3-E1 cells $\left(8.0 \times 10^{3}\right.$ cells/well, $0.5 \mathrm{ml} /$ well $)$ seeded in 48-well tissue culture plates were cultured for 1 day in $5 \% \mathrm{CO}_{2}$ at $37^{\circ} \mathrm{C}$ and treated with EMWI at 500,750 , and $1,000 \mathrm{kHz}, 5$ times $(1 \mathrm{sec} /$ time). To determine cell proliferation activity, a TetraColor ONE Cell Proliferation Assay System (Seikagaku Biobusiness Co., Tokyo, Japan) was used, as described in the manufacturer's instructions. Briefly, $50 \mu \mathrm{l}$ of TetraColor ONE was added to each well and the plates were incubated for $2 \mathrm{~h}$. Tetrazolium monosodium salt present in TetraColor ONE was reduced by mitochondrial dehydrogenase in live cells, and the concentration of formazan produced was in proportion to the number of live cells. Proliferation, reflected by the amount of formazan, was then measured using a microplate reader (Bio-Rad Laboratories, Hercules, CA, USA) at $450 \mathrm{~nm}$ with a contrast wavelength of $655 \mathrm{~nm}$. In addition to the assay based on mitochondrial activity, other cell proliferation assays, which do not rely metabolic status of the cell, were used. A Quantos Cell Proliferation Assay kit (Stratagene, La Jolla, CA, USA) was used to measure the amount of DNA in cells and a Bromodeoxyuridine (BrdU) Cell Proliferation Assay (EMD Millipore Co., San Diego, CA, USA) was used to measure BrdU incorporated into newly synthesized DNA strands of actively proliferation cells during the indicated 24-h culture, as described in the manufacturer's instructions.

\section{Cell Cytotoxicity Assay}

The effect of EMWI on cell cytotoxicity was determined using a lactate dehydrogenase (LDH) assay. MC3T3-E1 cells $\left(1.8 \times 10^{4}\right.$ cells/well, $0.5 \mathrm{ml} /$ well $)$ seeded in 48-well tissue culture plates were cultured for 1 day in $5 \% \mathrm{CO}_{2}$ at $37^{\circ} \mathrm{C}$ and treated by EMWI at $500 \mathrm{kHz}, 5$ times $(1 \mathrm{sec} /$ time). As a positive control, MC3T3-E1 cells were treated with $0.1 \%$ Triton X-100 and shaken gently for $10 \mathrm{~min}$ at room temperature. At 1,3 , or 5 days after EMWI, the levels of LDH in the recovered cell culture supernatants were determined using an LDH cytotoxicity assay kit (Cayman Chemical Co., Ann Arbor, MI, USA) in accordance with the manufacturer's instructions. Absorbance was measured at $490 \mathrm{~nm}$ using a microplate reader (Bio-Rad Laboratories).

\section{Quantitative real-time PCR}

Total RNA was isolated from EMWI-treated or non-irradiated control MC3T3-E1 cells $\left(1.0 \times 10^{5}\right.$ cells/ $\mathrm{ml}, 0.5 \mathrm{ml} /$ well) using a NucleoSpin RNA kit (MACHEREY-NAGEL, Düren, Germany) in accordance with the manufacturer's instructions. The concentration of purified total RNA was measured using NanoDrop ND-1000 (Thermo Fisher Scientific, Waltham, MA, USA). Total RNA (400 ng) was used to synthesize 
Yumoto et al.: Electromagnetic Activation of Osteoblasts

Table 1. Oligonucleotide sequences of primers used for quantitative real-time PCR

\begin{tabular}{|c|c|c|}
\hline Gene & Sequence (forward, reverse) & Size of PCR fragment (bp) \\
\hline VEGF & $\begin{array}{l}\text { 5'-AACGATGAAGCCCTGGAGT-3' } \\
\text { 5'-AGGTTTGATCCGCATGATCT-3' }\end{array}$ & 72 \\
\hline PDGF-A & $\begin{array}{l}\text { 5'-GTGCGACCTCCAACCTGA-3' } \\
\text { 5'-GGCTCATCTCACCTCACATCT-3' }\end{array}$ & 64 \\
\hline PDGF-B & $\begin{array}{l}\text { 5'-ACTCCATCCGCTCCTTTGA-3' } \\
\text { 5'-AGCTCAGCCCCATCTTCAT-3' }\end{array}$ & 73 \\
\hline TGF- $\beta 1$ & $\begin{array}{l}\text { 5'-GGATACCAACTATTGCTTCAGCTCC-3' } \\
\text { 5'-AGGCTCCAAATATAGGGGCAGGGTC-3' }\end{array}$ & 156 \\
\hline FGF-2 & $\begin{array}{l}\text { 5'-ACCTTGCTATGAAGGAAGATGG-3' } \\
\text { 5'-CAGTCGTTCAAAGAAGAAACACTC-3 }\end{array}$ & 77 \\
\hline CTGF & $\begin{array}{l}\text { 5'-CTGCAGACTGGAGAAGCAGA-3' } \\
\text { 5'-GATGCACTTTTTGCCCTTCTT-3' }\end{array}$ & 91 \\
\hline Osteopontin & $\begin{array}{l}\text { 5'-CCAGGTTTCTGATGAACAGTATCC-3' } \\
\text { 5'-ACTTGACTCATGGCTGCCCTTT-3' }\end{array}$ & 163 \\
\hline Actin & $\begin{array}{l}\text { 5'-GGATGCAGAAGGAGATTACTGC-3' } \\
\text { 5'-CCACCGATCCACACAGAGTA-3' }\end{array}$ & 94 \\
\hline
\end{tabular}

cDNA using a SuperScript ${ }^{\mathrm{TM}}$ III First-Strand Synthesis System (Invitrogen, Carlsbad, CA, USA). Real-time PCR was performed in a LightCycler Quick System 305S (Roche Diagnostics, Mannheim, Germany) using a LightCycler FastStart DNA Master ${ }^{\text {plus }}$ SYBR Green I Kit (Roche Diagnostics), as described in the manufacturer's instructions. The "Second Derivative Maximum Method" was performed using LightCycler software 3.5 (Roche Diagnostics) to analyze the results. For each target gene and control gene actin RNA, a purified PCR product (137-617 bp) amplified from cDNA was used to create a quantitative standard curve and another primer pair was designed for the LightCycler reaction to generate PCR products of 64-163 bp (Table 1).

ELISA for growth factors and osteopontin

The concentrations of vascular endothelial growth factor (VEGF), platelet-derived growth factor (PDGF)-AA, PDGF-AB, PDGF-BB, osteopontin and TGF- $\beta 1$ in cell culture supernatants were determined using a Quantikine ELISA kit (R\&D Systems, Minneapolis, MN, USA) as described in the manufacturer's instructions.

Detection of phospho-specific MAPK activation

For analysis of the signal transduction pathway, EMWI-treated or non-irradiated control MC3T3-E1 cells $\left(1.0 \times 10^{5}\right.$ cells $/ \mathrm{ml}, 0.5 \mathrm{ml} /$ well $)$ were washed once with cold phosphate-buffered saline followed by incubation on ice for $30 \mathrm{~min}$ with RIPA lysis buffer supplemented with protease and phosphatase inhibitors (Santa Cruz Biotechnology, Santa Cruz, CA, USA). After removal of debris by centrifugation, protein concentrations in the lysates were quantified using a Bicinchoninic Acid Protein Assay Kit (Sigma-Aldrich, St. Louis, MO, USA) using bovine serum albumin as a standard. Protein samples ( $8 \mu \mathrm{g})$ were separated on a $4-20 \%$ sodium dodecyl sulfate (SDS) polyacrylamide gel followed by electrotransfer onto a polyvinylidene difluoride membrane. Activation of extracellular signal-regulated kinase (ERK)1/2, p38 mitogen-activated protein kinase (MAPK), and stress-activated protein kinase (SAPK)/ c-jun $\mathrm{NH}_{2}$-terminal kinase (JNK) was assessed using a Phospho-MAPK Family Rabbit mAb Sampler Kit and MAPK Family Antibody Sampler Kit (Cell Signaling Technology, Danvers, MA, USA) in accordance with the manufacturer's instructions. Actin levels were also assessed as an internal control using an anti-actin antibody (Sigma-Aldrich; 1:250 dilution). Protein bands were visualized by incubation with the horseradish peroxidase-conjugated secondary antibody (1:2,000 dilution) followed by detection using ECL Prime Western Blotting Detection Reagent (GE Healthcare, Buckinghamshire, UK). For evaluation of the activity of MAPK, the ratio of phosphorylated MAPK molecule and total MAPK molecule was analyzed by densitometric analysis with ImageJ 1.47 software (NIH, USA) after normalization with actin. 
Fig. 1. EMWI does not exert cytotoxicity on osteoblastic cells. Confluent MC3T3-E1 cells monolayers in a 48-well plate were treated with EMWI at $500 \mathrm{kHz}$ ( 5 times, $1 \mathrm{sec} /$ time). Then, the plate was incubated at $37^{\circ} \mathrm{C}$ for 5 days. (A) Representative phase contrast micrographs of non-irradiated control and EMWI-treated MC3T3-E1 cells throughout the 5 days culture period at x 10 magnification. (B) As a positive control, MC3T3-E1 cells were treated with $0.1 \%$ Triton $\mathrm{X}-100$ and gently shaken for $10 \mathrm{~min}$ at room temperature. The levels of LDH in recovered cell culture supernatants were determined. Values represent the means \pm SDs from representative of two independent experiments and each experiment was performed in quadruplicate. ${ }^{*} P<0.01$ versus non-irradiation control.

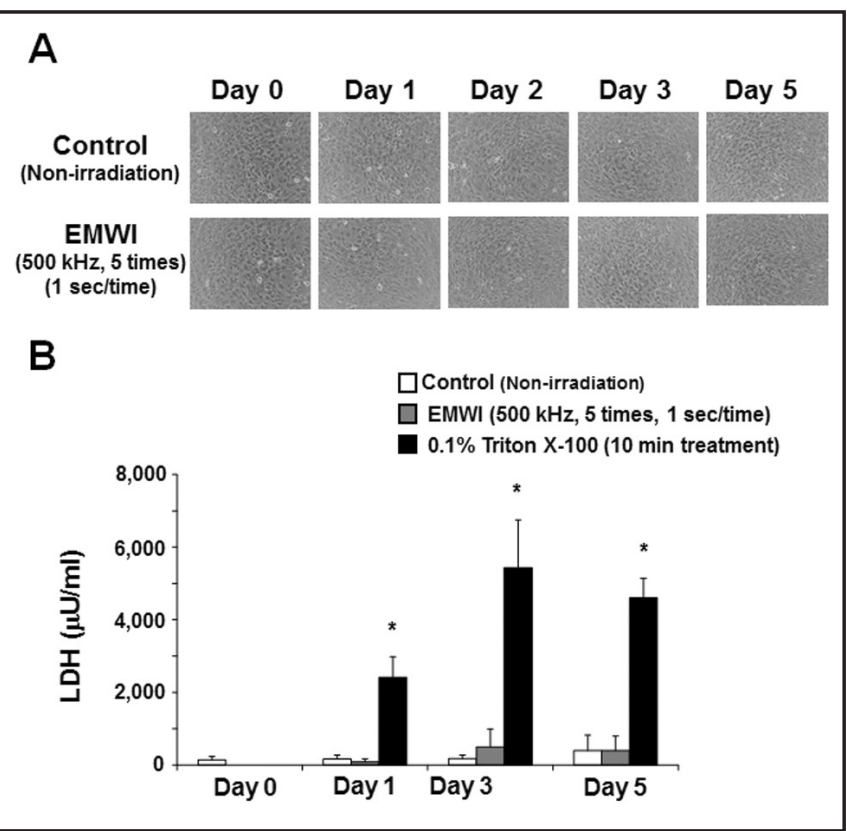

Analysis of EMWI-treated cell signal transduction pathways

MC3T3-E1 cells $\left(1.0 \times 10^{5}\right.$ cells $/ \mathrm{ml}, 0.5 \mathrm{ml} /$ well $)$ were seeded in 48 -well tissue culture plates and were incubated for 1 day in $5 \% \mathrm{CO}_{2}$ at $37^{\circ} \mathrm{C}$. For cell signaling analysis, cells were pretreated with the following specific inhibitors: PD98059 (for ERK1/2; $50 \mu \mathrm{M}$ ), SP600125 (for JNK; $20 \mu \mathrm{M}$ ), and SB203580 (for p38 MAPK; $20 \mu \mathrm{M}$ ), at $30 \mathrm{~min}$ prior to EMWI. Culture supernatants were collected at the indicated times and stored at $-20^{\circ} \mathrm{C}$ until assayed.

\section{Statistical analysis}

Data are presented as mean \pm SDs. The data corresponding to the EMWI-treated group and the respective control group were compared by unpaired Student's $t$ test. The multifactorial one way analysis of variance (ANOVA) with Dunnett's post hoc test was used to assess differences between multiple sets of data. Differences were considered significant when the probability value was less than $5 \%(P<0.05)$.

\section{Results}

\section{EMWI does not exert cytotoxicity on osteoblastic cells}

First, we investigated the influence of EMWI on osteoblastic cells morphology. EMWI $(500,750$ and $1,000 \mathrm{kHz}, 5$ times, $1 \mathrm{sec} /$ time $)$ did not cause any morphological change in the irradiated MC3T3-E1 cells over a period of 5 days (Fig. 1A at $500 \mathrm{kHz}$, data not shown at 750 and $1,000 \mathrm{kHz}$ ).

To confirm the absence of any cytotoxic effect of EMWI on osteoblastic cells, we next measured the level of LDH released from cells. As a positive control, MC3T3-E1 cells were treated with $0.1 \%$ Triton X-100 for $10 \mathrm{~min}$. As shown in Fig. 1B, no cytotoxic effect of EMWI at $500 \mathrm{kHz}, 5$ times, $1 \mathrm{sec} /$ time on MC3T3-E1 cells were observed.

To avoid tissue and cell damage by heating after EMWI, we further monitored the temperature of the culture medium during EMWI at $500 \mathrm{kHz}$. After 5 consecutive irradiations, the temperature of the culture medium increased to $40.0^{\circ} \mathrm{C}$ from $30.0^{\circ} \mathrm{C}$ before irradiation (Fig. 2). The temperature of the culture medium increased with the number of irradiations at the rate of approximately $2.0^{\circ} \mathrm{C}$ per irradiation. As the irradiation current was passed intermittently for only $1 \mathrm{sec} /$ time, the temperature decreased gradually after irradiation finished. These results indicated that EMWI does not damage osteoblastic cells morphologically, and suggested that heating by EMWI had little effect on osteoblastic cells. 
Fig. 2. EMWI produces only a small change in the temperature of the culture medium. The temperature of the cell culture medium during EMWI at 500 $\mathrm{kHz}$ ( $1 \mathrm{sec} /$ time) was monitored using a thermometer. Values represent the means \pm SDs from representative of two independent experiments and each experiment was performed in quadruplicate.

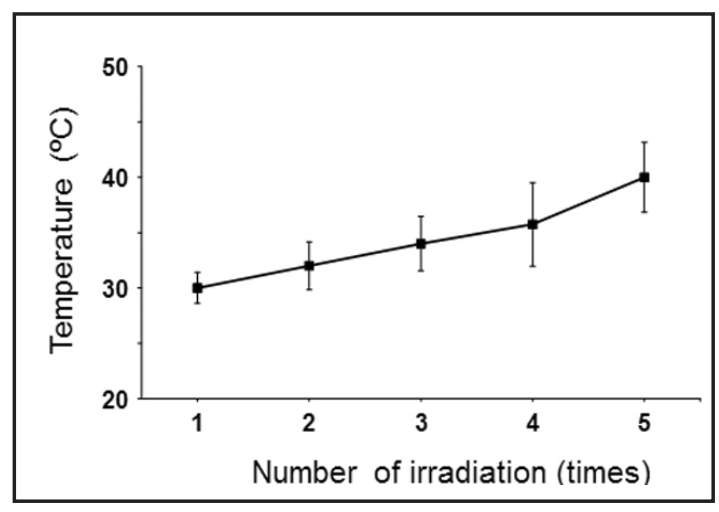

Fig. 3. EMWI stimulates the proliferation of osteoblastic cells. MC3T3-E1 cells were treated with EMWI at 500, 750, or $1,000 \mathrm{kHz}$ (5 times, $1 \mathrm{sec} /$ time). (A) Dehydrogenase assay-based TatraColor ONE, (B) DNA quantification-based Quantos Cell Proliferation Assay kit and (C) BrdU incorporation-based BrdU Cell Proliferation Assay were used to determine cell proliferation as described in the Materials and Methods section. Values represent the means \pm SDs from representative of four independent experiments and each experiment was performed in quadruplicate. ${ }^{*} P<0.05$, ${ }^{* *} P<0.01 \quad$ versus non-irradiated controls.

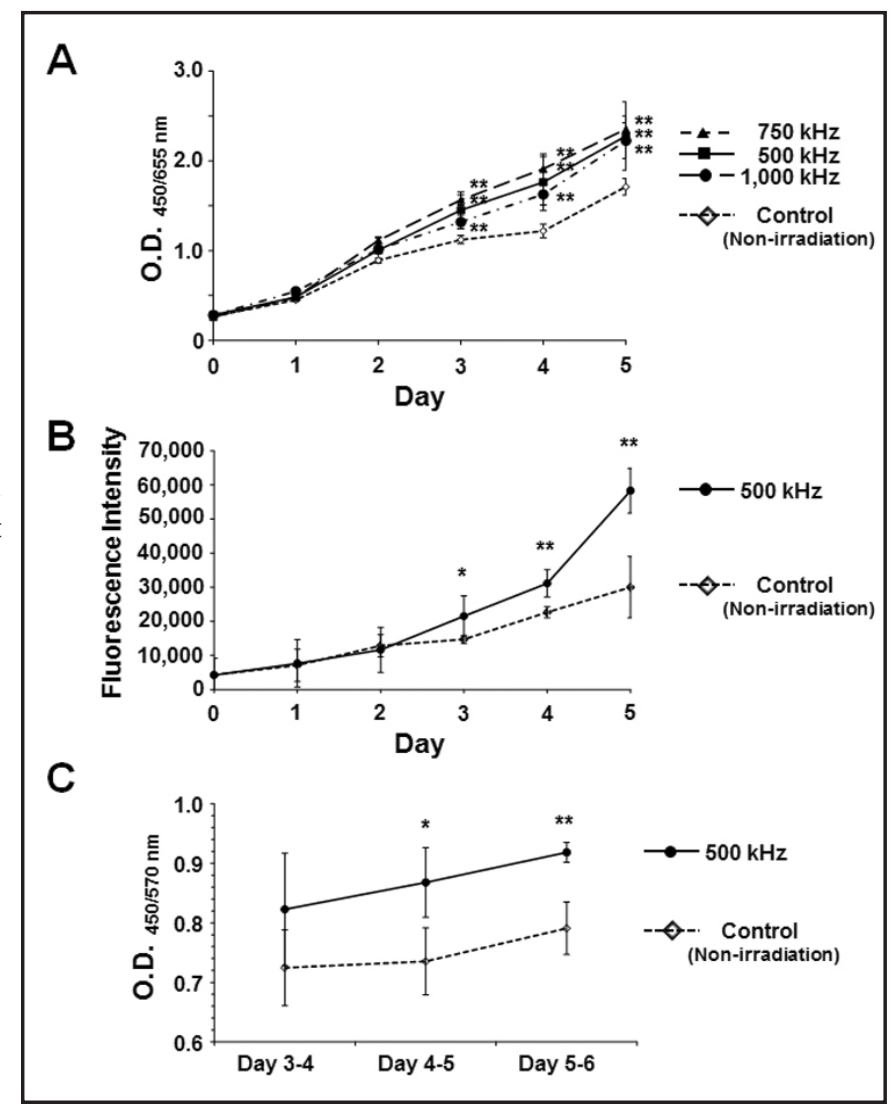

EMWI stimulates osteoblastic cell proliferation and transcriptional activity

We investigated the influence of EMWI on the proliferation of osteoblastic cells using 3 different types of assays. By the assay based on mitochondrial activity, the cell proliferation of irradiated cells was significantly activated after day 3, regardless of the frequency, compared with that in the non-irradiated control group (Fig. 3A). We also observed that the cell proliferation of osteoblastic cells irradiated at $500 \mathrm{kHz}$ was significantly activated after day 3 by the assay based on the amount of DNA in cells (Fig. 3B) and BrdU incorporated into the DNA of dividing cells between day 4 and 6 was significantly increased (Fig. 3C), compared with that in the non-irradiated cells. Moreover, total RNA increased significantly in the irradiated MC3T3-E1 cells 1 day after EMWI (Fig. 4) despite the fact that the cell proliferation was not activated on that day. These results suggest that EMWI stimulates the proliferation and the transcriptional activity of osteoblastic cells. 
Fig. 4. EMWI increases total RNA in osteoblastic cells. MC3T3-E1 cells were treated with EMWI at $500 \mathrm{kHz}$ ( 5 times, $1 \mathrm{sec} /$ time). Total RNA was isolated from EMWI-treated or non-irradiated MC3T3-E1 cells $\left(3.0 \times 10^{4}\right.$ cells/well) using a NucleoSpin RNA kit. The concentration of purified total RNA was measured using NanoDrop ND-1000. Values represent the means \pm SDs from representative of four independent experiments and each experiment was performed in quadruplicate. ${ }^{*} P<0.01$ versus nonirradiated controls.

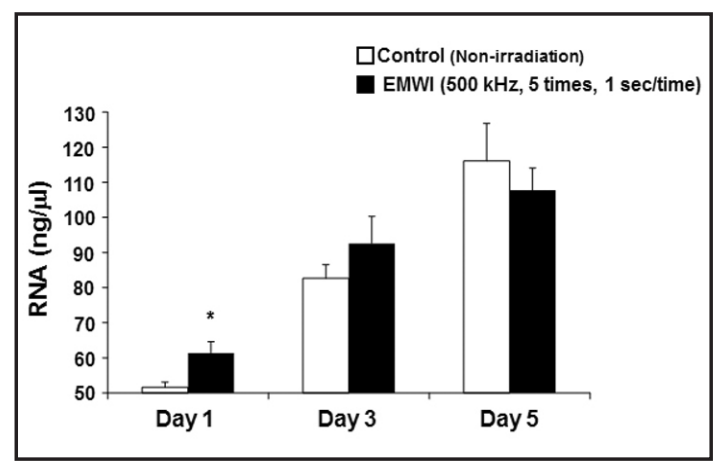

Fig. 5. EMWI up-regulates the gene expression of various growth factors and osteopontin in osteoblastic cells. Total RNA (400 ng) isolated from EMWI-treated or non-irradiated control MC3T3-E1 cells $\left(1.0 \times 10^{5}\right.$ cells $/ \mathrm{ml}, 0.5 \mathrm{ml} /$ well) was used for real-time PCR. Values represent the means \pm SDs from representative of four independent experiments and each experiment was performed in quadruplicate. ${ }^{*} P<0.05$, ${ }^{* *} P<0.01$ versus non-irradiated controls.

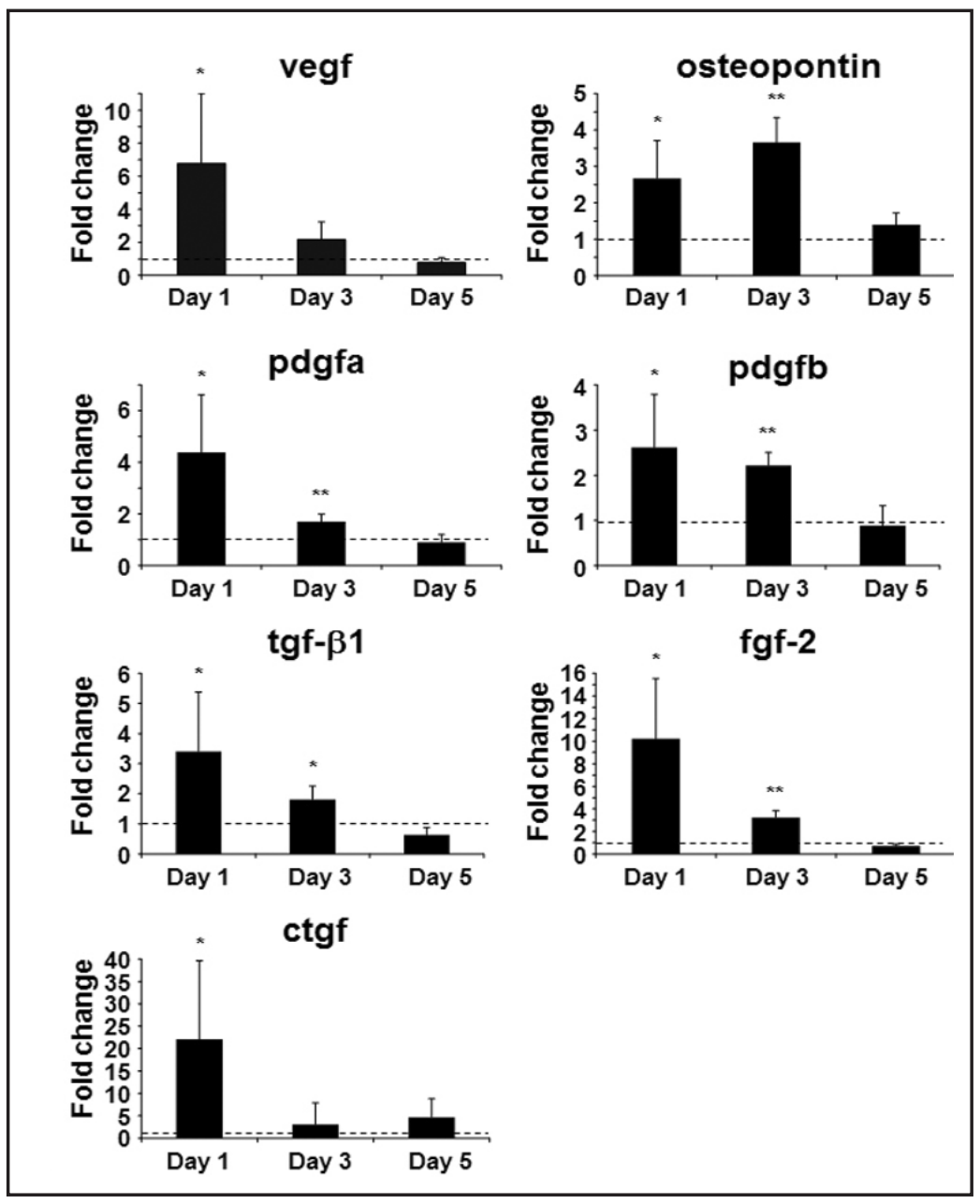

EMWI up-regulates gene expression and protein production of various growth factors and osteopontin in osteoblastic cells

Growth factors are involved in regulating cell viability and extracellular matrix remodeling during healing processes. We next determined whether EMWI can up-regulate the gene expression level of growth factors and osteopontin. Quantitative real-time RT-PCR validated the significant up-regulation of genes for growth factors (vegf, tgf- $\beta 1, p d g f a, p d g f b$, connective tissue growth factor (ctgf), and fibroblast growth factor $(f g f) 2$ ) and osteopontin (Fig. 5).

We also confirmed the production levels of growth factors (VEGF, PDGF-AA, PDGF-AB, PDGF-BB, and TGF- $\beta 1$ ) and osteopontin by ELISA (Fig. 6). The production levels of VEGF, 
Fig. 6. EMWI increases the protein production of various growth factors and osteopontin in osteoblastic cells. ELISA analysis of growth factors and osteopontin in non-irradiated control and EMWI-treated (at $500 \mathrm{kHz}, 5$ times, $1 \mathrm{sec} /$ time) MC3T3-E1 cells $\left(1.0 \times 10^{5}\right.$ cells $/ \mathrm{ml}, 0.5$ $\mathrm{ml} /$ well). Values represent the means \pm SDs from representative of four independent experiments and each experiment was performed in quadruplicate. ${ }^{*} P<0.05$, ${ }^{* *} P<0.01$ versus non-irradiated controls.
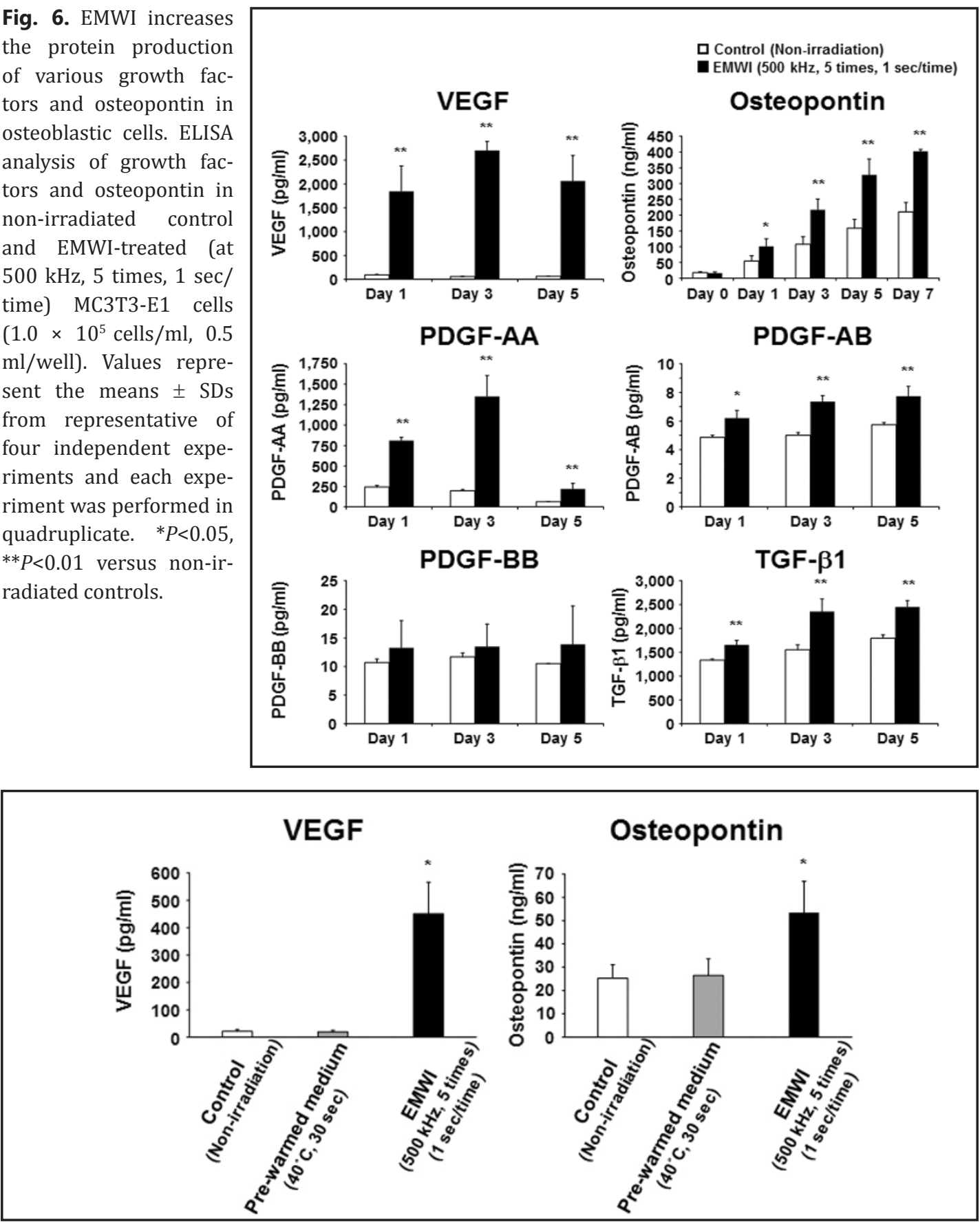

Fig. 7. A transient increase in temperature by EMWI does not affect the production of VEGF and osteopontin in osteoblastic cells. ELISA analysis of VEGF and osteopontin in non-irradiated control, pre-warmed medium-treated $\left(40^{\circ} \mathrm{C}, 30 \mathrm{sec}\right)$ and EMWI-treated (at $500 \mathrm{kHz}, 5$ times, $1 \mathrm{sec} /$ time) MC3T3-E1 cells $(1.0 \times$ $10^{5}$ cells $/ \mathrm{ml}, 0.5 \mathrm{ml} /$ well). Values represent the means \pm SDs from representative of four independent experiments and each experiment was performed in quadruplicate. ${ }^{*} P<0.01$ versus non-irradiated controls.

PDGF-AA, PDGF-AB, TGF- $\beta 1$ and osteopontin, but not PDGF-BB, in EMWI-treated cells were significantly increased on day 1 after irradiation and produced continuously for 5 or 7 days after irradiation. Regarding PDGFs, the increased level of PDGF-AA was significantly higher than that of PDGF-AB, suggesting that PDGF-AA is a predominant form in EMWItreated MC3T3-E1 cells. 
Fig. 8. EMWI activates MAPKs and SAPK/JNK signaling pathways in osteoblastic cells. (A) Immunoblotting analysis of ERK1/2, p38 MAPK and SAPK/JNK in non-irradiated control and EMWI-treated (at $500 \mathrm{kHz}, 5$ times, $1 \mathrm{sec} /$ time) MC3T3-E1 cells. Equal loading of gels was confirmed with both SDS-PAGE (data not shown) and immunoblotting using an anti-actin antibody. The results shown are representative images of three independent experiments with similar results. (B) Densitometric analysis of SAPK/JNK, ERK and p38 MAPK expressions. Bars indicate the ratio of phosphorylated protein/total protein after the values were normalized with actin. The quantitative analysis of the bands are shown in the bar graphs. Values represent the means \pm SDs of three independent experiments. ${ }^{*} P<0.01$ versus non-irradiated controls.

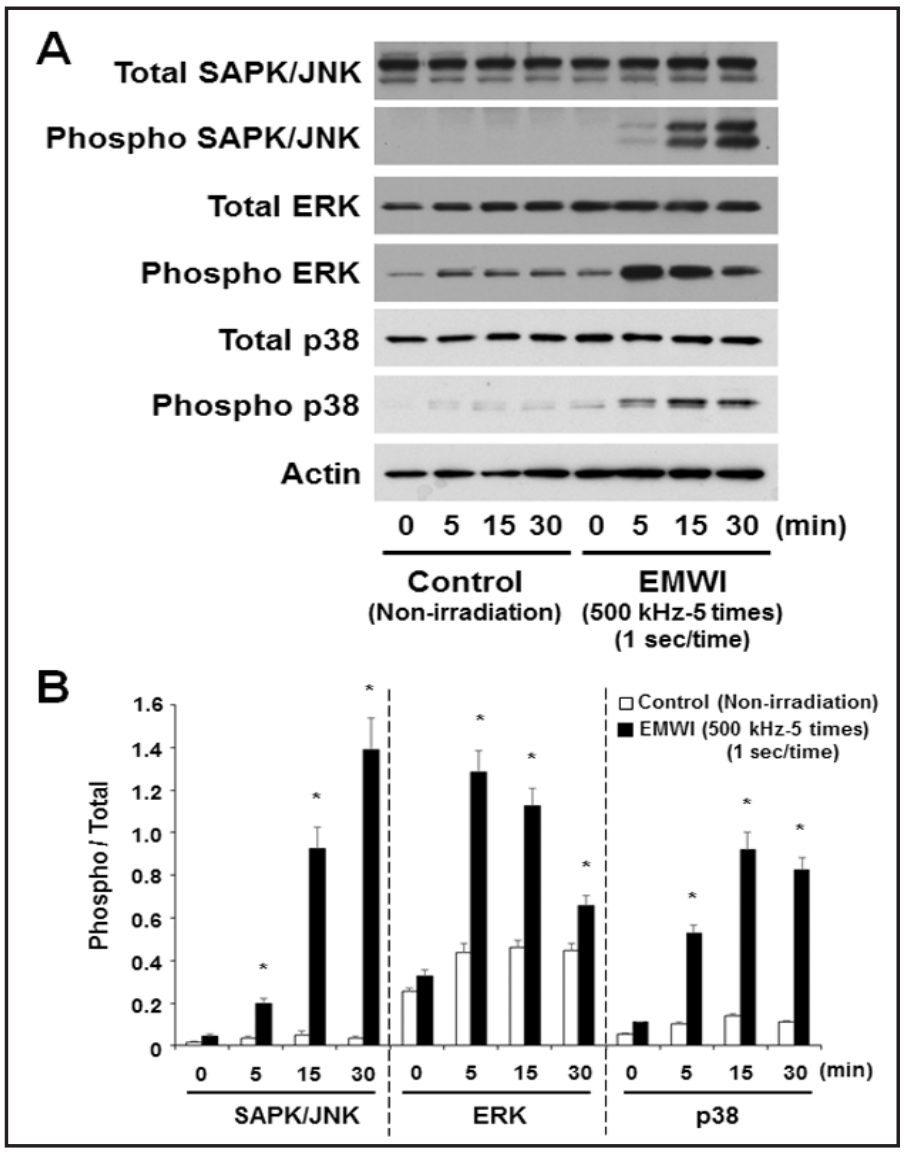

To further determine whether a transient increase in temperature by EMWI affect the production levels of growth factor and osteopontin, MC3T3-E1 cells was treated with prewarmed medium at $40^{\circ} \mathrm{C}$ for $30 \mathrm{sec}$ and then replaced by the normal medium to culture for 24 hrs at $37^{\circ} \mathrm{C}$ (Fig. 7). Pre-warmed medium treatment did not make MC3T3-E1 cells to increase VEGF and osteopontin productions, suggesting that a transient increase in temperature by EMWI does not affect the production of growth factors and osteopontin in MC3T3-E1 cells.

EMWI regulates the protein production of VEGF, PDGF-AA and osteopontin via MAPKS signaling pathways in osteoblastic cells

Reports have shown recently that low-level Er:YAG laser irradiation enhances osteoblast proliferation through activation of the ERK1/2 MAPK pathway [34] and the induction of FGF2 gene expression by mechanical stress is dependent on the ERK1/2 MAPK signal transduction pathway [35]. To elucidate the mechanism by which EMWI regulates the gene expression and protein production of various growth factors and osteopontin, we first tested the ability of EMWI to activate major cell signal transduction pathways, such as ERK1/2, p38 MAPK and SAPK/JNK. Immunoblotting analysis of ERK1/2, p38 MAPK and SAPK/JNK revealed that significant activation of all tested signal transduction molecules occurred within 5 min after EMWI and continued for 30 min (Fig. 8).

We next examined the involvement of these major cell signal transduction pathways using specific inhibitors in the protein production of growth factors and osteopontin. MC3T3-E1 cells were pretreated with specific inhibitors PD98059 (ERK1/2 inhibitor), SB203580 (p38 MAPK inhibitor) or SP600125 (JNK inhibitor) at 30 min prior to EMWI at $500 \mathrm{kHz}$ (5 times, $1 \mathrm{sec} /$ time) (Fig. 9). Inductions of VEGF and PDGF-AA were partially reduced by $\mathrm{p} 38$ MAPK inhibitor and ERK1/2 inhibitor, respectively. Moreover, induction of osteopontin was partially reduced by all tested inhibitors and strongly decreased to almost baseline levels by ERK1/2 inhibitor. 
Fig. 9. EMWI regulates the protein production of VEGF, PDGF-AA and osteopontin via MAPKs and SAPK/ JNK signaling pathways in osteoblastic cells. ELISA analysis of protein production levels of VEGF, PDGF-AA and osteopontin in non-irradiated control and EMWI-treated (at 500 $\mathrm{kHz}, 5$ times, $1 \mathrm{sec} /$ time) MC3T3-E1 cells. MC3T3-E1 cells were pre-incubated with SP600125 $(20 \mu \mathrm{M})$, SB203580 $(20 \mu \mathrm{M})$, or PD98059 (50 $\mu \mathrm{M}$ ) for $30 \mathrm{~min}$ prior to EMWI. Values represent the means \pm SDs from representative of four independent experiments and each experiment was performed in quadruplicate. $* P<0.05$, ${ }^{* *} P<0.01$ versus non-inhibitor controls. \#\# $P<0.01$ versus non-irradiated controls.

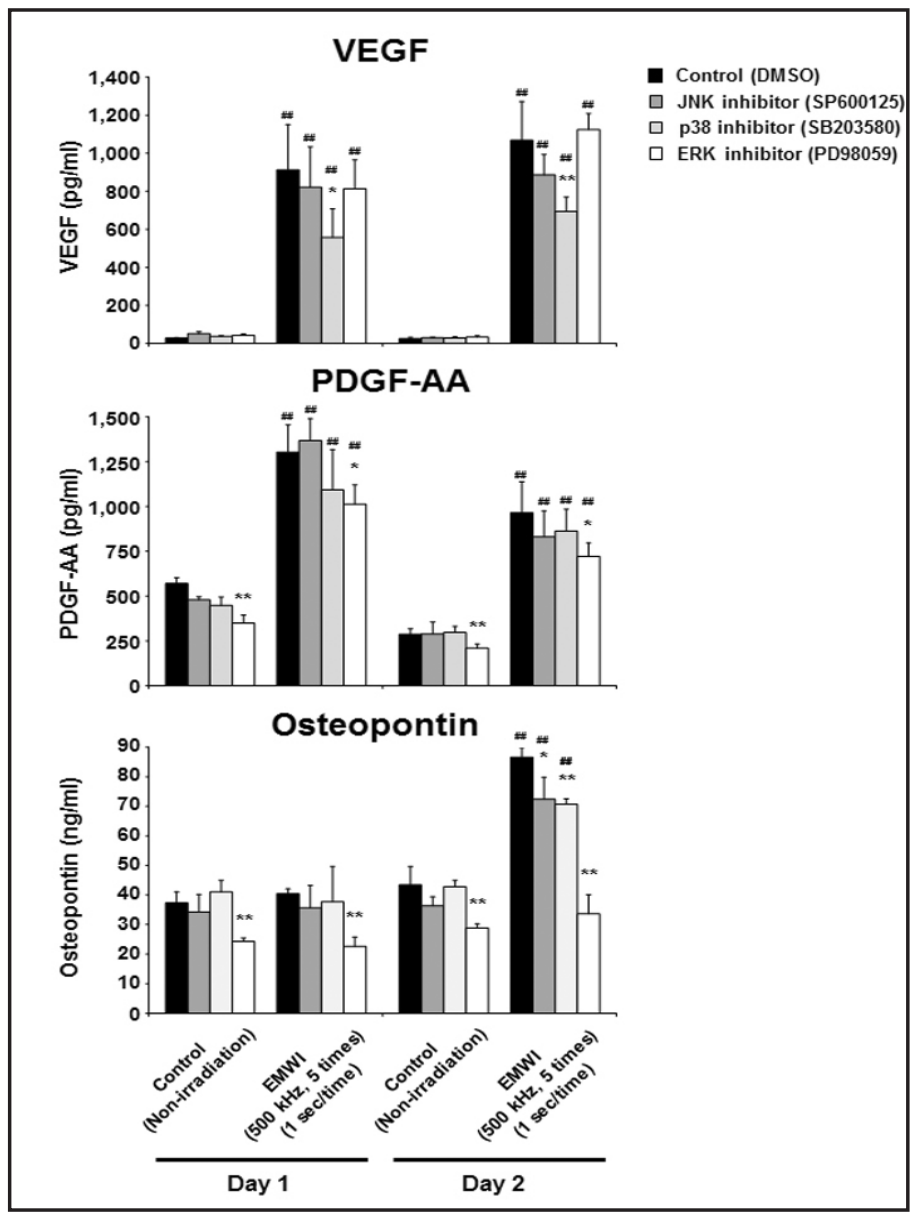

\section{Discussion}

Recently, we demonstrated that the bactericidal effect of EMWI on selected oral pathogens [28]. A substantial number of preliminary in vitro, in vivo animal and clinical studies have demonstrated that electric energy is an important tool for enhancing bone formation. For example, electric energy has been used clinically to treat fresh, delayed or nonunion fractures, osteotomies and spine fusions [30]. We tried to determine the potential ability of EMWI as regenerative therapy for bone involvement, such as periapical and marginal periodontitis. Therefore, the current study extends our knowledge on the activating effects of EMWI on MC3T3-E1 osteoblastic cells to evaluate the possible use of EMWI to enhance the healing of periodontal lesions. This study demonstrated that EMWI enhanced osteoblastic cell proliferation and induced the gene expression of growth factors, including TGF- $\beta 1$, VEGF, FGF2 and PDGF, and the extracellular structural protein of bone, osteopontin.

To avoid tissue and cell damage by EMWI, we first verified that EMWI at $500 \mathrm{kHz}$ (5 times, $1 \mathrm{sec} /$ time) was not especially cytotoxic, and did not cause any morphological change in MC3T3-E1 cells over a period of 5 days (Fig. 1). We further confirmed that the temperature increased to $40.0^{\circ} \mathrm{C}$ from $30.0^{\circ} \mathrm{C}$ before irradiation after 5 consecutive irradiations and then decreased gradually after stopping irradiation because the irradiation current was passed intermittently for only $1 \mathrm{sec} /$ time (Fig. 2). These results indicated that EMWI does not damage osteoblastic cells, suggesting that EMWI is safe to use for clinical applications.

EMWI at 500, 750 and 1,000 kHz (5 times, $1 \mathrm{sec} /$ time) could also stimulate osteoblastic cell proliferation (Fig. 3). This finding appears to be in agreement with previous studies using various laser systems, which have shown laser-induced osteoblastic cell proliferation $[15,34]$. Interestingly, one previous study showed an association between mechanical stimulation by pulse irradiation and an increase in osteoblast activity [36], and another 
study reported that electrical stimulation using an electric field significantly increased cell proliferation of osteoblasts [33]. Therefore, pulsed EMWI used in this study may have the potential to activate osteoblasts in periodontal tissues surrounding a tooth and to promote wound healing and bone tissue regeneration.

Our results also showed that total RNA was significantly increased in MC3T3-E1 cells 1 day after EMWI irradiation (Fig. 4). This result strongly suggests transcriptional activation by EMWI. Because growth factors are involved in regulating cell viability and extracellular matrix remodeling during healing processes, we focused on growth factors and osteopontin and determined their expression and production levels and the mechanisms induced by EMWI. Using quantitative real-time PCR and ELISA, the expression and production levels of growth factors (vegf, tgf- $\beta 1, p d g f a, p d g f b, c t g f$, and $f g f 2$ ) and osteopontin in EMWI-treated cells were significantly increased on day 1 after irradiation and continuously up-regulated during 1-3 days and 5-7 days after irradiation, respectively (Fig. 5, 6). Moreover, a transient increase in temperature using pre-warmed medium did not affect the production of growth factor and osteopontin in MC3T3-E1 cells (Fig. 7), suggesting that EMWI-mediated activation of osteoblastic cells is not derived from a transient increased temperature. These results suggested that the up-regulation of growth factors and osteopontin may play a crucial role in regulating the viability and activation of osteoblastic cells after EMWI.

Migration of bone-forming osteoblastic cells is also thought to be important in many pathologic processes and bone physiology, including bone remodeling and fracture repair. Many local growth factors, including VEGF, PDGF, TGF- $\beta$ and FGF, can promote migration in a variety of cell types and have been proposed as therapeutic agents in wound healing and fracture $[37,38]$. Moreover, most growth factors are potent stimulators of cell proliferation.

It has been considered that angiogenesis is a prerequisite for bone formation along with close cross-talk between osteoblasts and endothelial cells [39, 40]. VEGF secreted from osteoblasts functions as a paracrine factor for neovascularization and causes endothelial cells to proliferate and stimulate blood vessel formation in bone tissue [41, 42]. In accordance with our present results, it has been reported that a biphasic electrical current coupled with an electromagnetic field can stimulate cell proliferation and up-regulate VEGF expression in osteoblasts [30].

The PDGF family consists of 5 different dimeric proteins built from four different peptide chains [43]. PDGF is a potent mitogen and chemo-attractant for multiple types of cells including osteoblasts and osteoprogenitor cells and responsible for stimulating angiogenesis, and it has been documented that PDGF stimulates the proliferation of stem cells as its important role in the biology of fracture healing [44-49]. Our results suggest that PDGF-AA and PDGF-AB up-regulated by EMWI may act as the mitogen and chemoattractant for various cells, which are necessary for bone tissue regeneration.

Several members of the TGF- $\beta$ superfamily, including TGF- $\beta 1$, modulate osteoblast differentiation and mineralization. TGF- $\beta$ can also induce the synthesis of bone matrix proteins in osteoblasts as well as most major extracellular matrix proteins [50]. Therefore, up-regulation of TGF- $\beta 1$ in osteoblastic cells by EMWI may play an important role in the production of extracellular matrix proteins during wound healing.

FGFs are involved in diverse cellular processes including cell differentiation and cell survival [51]. In particular, FGF2 stimulates MC3T3-E1 cell proliferation and differentiation in vitro [52]. Recent studies have shown that the efficacy of a human recombinant FGF2 for periodontal tissue regeneration was evaluated in a multi-center clinical trial and an application of FGF2 increased the rate of bone formation in individuals with fractures [5355]. An in vivo study has also shown that FGF2 accelerates angiogenesis in necrotic bone [56]. Therefore, FGF2 up-regulated in osteoblastic cells by EMWI may be one of the most promising factors as shown in a clinical trial and an in vivo study.

CTGF, a member of the CCN family of proteins, is a secreted, extracellular matrixassociated protein in a variety of tissues, including bone, and acts as an autocrine or paracrine regulator of various cellular functions, such as proliferation, migration, matrix production and differentiation, with its specific effects being target-cell dependent [57]. 
Previous reports have demonstrated that CTGF is necessary for osteoblastogenesis and required for normal osteoblastic function, and addition or overexpression of CTGF promotes osteoblast differentiation and function in cells of an osteoblastic lineage [58-61]. CTGF has also been implicated in more complex biological processes, including angiogenesis and fracture repair [62-64]. Considering our findings and previous studies, EMWI-up-regulated CTGF may play an important role in the osteogenic response and then lead to bone formation and remodeling.

Osteopontin is one of the extracellular matrix proteins synthesized by osteoblastic cells during bone development and a cytokine that has been suggested to act in a number of physiological and pathological events including bone remodeling [65-67]. Consistent with a previous report showing that Nd:YAG laser irradiation could stimulate osteoblastic cells to increase the expression of osteopontin [15], EMWI could continuously up-regulate ospteopontin production for 7 days.

MAPKs are serine/threonine kinases that phosphorylate transcription factors and other downstream kinases, mediating cellular signal transduction from the cell surface to the nucleus, and are responsible for many biological activities and cellular processes, such as proliferation and differentiation [68]. Three distinct groups of MAPKs: ERK, SAPK/JNK and p38 MAPK, have been identified. In particular, it has been shown that MAPKs are differentially expressed in different cell types and strongly correlated with cell proliferation as a reaction to extracellular stimuli [69]. Furthermore, normal osteoblast-specific gene expression and differentiation in vitro require MAPKs $[70,71]$. It is also well accepted that these MAPKs are activated by growth factors $[69,72,73]$. Our results demonstrated that EMWI strongly increased MAPK phosphorylation and activated the MAPK pathways compared with those of unirradiated control cells (Fig. 8). Moreover, a p38 MAPK-specific inhibitor significantly inhibited VEGF production, and ERK-specific inhibitor strongly reduced the production of PDGF-AA and osteopontin. A JNK inhibitor could also inhibit osteopontin weakly. These findings indicated that the up-regulation of growth factors and osteopontin is mediated by these MAPKs pathways. A previous study also indicated a strong correlation between osteoblast proliferation using low-level Er:YAG laser irradiation and specific activation of MAPKs [34]. Therefore, EMWI-induced growth factors in osteoblasts may be able to activate the surrounding cells by autocrine and paracrine mechanisms and finally lead to bone tissue regeneration.

In conclusion, EMWI significantly induced osteoblast proliferation and up-regulated the transcriptional and protein levels of growth factors and osteopontin, indicating that EMWI can efficiently switch on some potential regulator of growth factors, which may be important for bone regeneration mediated by osteoblasts. This study is valuable in its assessment of EMWI using an in vitro model as a new type of electrical stimulation for osteogenesis and raises the possibility that EMWI could be a useful new method for promoting bone tissue regeneration, such as in periodontal tissues.

\section{Acknowledgements}

This work was supported in part by a Grant-in Aid for Scientific Research (23390435, 21592423 and 26462885) from the Ministry of Education, Science and Culture of Japan. All authors state that they have no conflicts of interest.

\section{References}

1 Pihlstrom BL, Michalowicz BS, Johnson NW: Periodontal diseases. Lancet 2005;366:1809-1820.

2 Offenbacher S: Periodontal diseases: Pathogenesis. Ann. Periodontol 1996;1:821-878.

-3 Fouad AF, Barry J, Caimano M, Clawson M, Zhu Q, Carver R, Hazlett K, Radolf JD: PCR-based identification of bacteria associated with endodontic infections. J Clin Microbiol 2002;40:3223-3231.

-4 Munson MA, Pitt-Ford T, Chong B, Weightman A, Wade WG: Molecular and cultural analysis of the microflora associated with endodontic infections. J Dent Res 2002;81:761-766. 
Yumoto et al.: Electromagnetic Activation of Osteoblasts

5 Rolph HJ, Lennon A, Riggio MP, Saunders WP, MacKenzie D, Coldero L, Bagg J: Molecular identification of microorganisms from endodontic infections. J Clin Microbiol 2001;39:3282-3289.

6 Siqueira JF, Jr., Rocas IN, Paiva SS, Magalhaes KM, Guimaraes-Pinto T: Cultivable bacteria in infected root canals as identified by 16S rRNA gene sequencing. Oral Microbiol Immunol 2007;22:266-271.

7 Polansky R, Haas M, Heschl A, Wimmer G: Clinical effectiveness of photodynamic therapy in the treatment of periodontitis. J Clin Periodontol 2009;36:575-580.

8 Slot DE, Kranendonk AA, Paraskevas S, Van der Weijden F: The effect of a pulsed Nd:YAG laser in nonsurgical periodontal therapy. J Periodontol 2009;80:1041-1056.

-9 Aoki A, Sasaki KM, Watanabe H, Ishikawa I: Lasers in nonsurgical periodontal therapy. Periodontol 2000 2004;36:59-97.

10 Schwarz F, Aoki A, Becker J, Sculean A: Laser application in non-surgical periodontal therapy: A systematic review. J Clin Periodontol 2008;35:29-44.

11 Sculean A, Schwarz F, Berakdar M, Windisch P, Arweiler NB, Romanos GE: Healing of intrabony defects following surgical treatment with or without an Er:YAG laser. J Clin Periodontol 2004;31:604-608.

12 Crespi R, Cappare P, Toscanelli I, Gherlone E, Romanos GE: Effects of Er:YAG laser compared to ultrasonic scaler in periodontal treatment: A 2-year follow-up split-mouth clinical study. J Periodontol 2007;78:11951200.

13 Aoki A, Mizutani K, Takasaki AA, Sasaki KM, Nagai S, Schwarz F, Yoshida I, Eguro T, Zeredo JL, Izumi Y: Current status of clinical laser applications in periodontal therapy. Gen Dent 2008;56:674-687; quiz 688$679,767$.

14 Schwarz F, Aoki A, Sculean A, Becker J: The impact of laser application on periodontal and peri-implant wound healing. Periodontol 2000 2009;51:79-108.

15 Chellini F, Sassoli C, Nosi D, Deledda C, Tonelli P, Zecchi-Orlandini S, Formigli L, Giannelli M: Low pulse energy Nd:YAG laser irradiation exerts a biostimulative effect on different cells of the oral microenvironment: "An in vitro study". Lasers Surg Med 2010;42:527-539.

16 Pourzarandian A, Watanabe H, Ruwanpura SM, Aoki A, Ishikawa I: Effect of low-level Er:YAG laser irradiation on cultured human gingival fibroblasts. J Periodontol 2005;76:187-193.

17 Pourzarandian A, Watanabe H, Ruwanpura SM, Aoki A, Noguchi K, Ishikawa I: Er:YAG laser irradiation increases prostaglandin E production via the induction of cyclooxygenase-2 mRNA in human gingival fibroblasts. J Periodontal Res 2005;40:182-186.

18 Krause F, Braun A, Brede O, Eberhard J, Frentzen M, Jepsen S: Evaluation of selective calculus removal by a fluorescence feedback-controlled Er:YAG laser in vitro. J Clin Periodontol 2007;34:66-71.

19 Schwarz F, Sculean A, Berakdar M, Georg T, Reich E, Becker J: Clinical evaluation of an Er:YAG laser combined with scaling and root planing for non-surgical periodontal treatment. A controlled, prospective clinical study. J Clin Periodontol 2003;30:26-34.

20 Schwarz F, Sculean A, Berakdar M, Szathmari L, Georg T, Becker J: In vivo and in vitro effects of an Er:YAG laser, a GaAlAs diode laser, and scaling and root planing on periodontally diseased root surfaces: A comparative histologic study. Lasers Surg Med 2003;32:359-366.

-21 Sculean A, Schwarz F, Berakdar M, Romanos GE, Arweiler NB, Becker J: Periodontal treatment with an Er:YAG laser compared to ultrasonic instrumentation: A pilot study. J Periodontol 2004;75:966-973.

22 Vassalli M, Giannelli M: Effect of Nd: YAG laser on titanium dental implants studied by AFM. Ital J Anat Embryol 2003;108:195-203.

23 Giannini R, Vassalli M, Chellini F, Polidori L, Dei R, Giannelli M: Neodymium:Yttrium aluminum garnet laser irradiation with low pulse energy: A potential tool for the treatment of peri-implant disease. Clin Oral implants Res 2006;17:638-643.

24 Giannelli M, Bani D, Tani A, Pini A, Margheri M, Zecchi-Orlandini S, Tonelli P, Formigli L: In vitro evaluation of the effects of low-intensity Nd:YAG laser irradiation on the inflammatory reaction elicited by bacterial lipopolysaccharide adherent to titanium dental implants. J Periodontol 2009;80:977-984.

25 Prates RA, Yamada AM, Jr., Suzuki LC, Eiko Hashimoto MC, Cai S, Gouw-Soares S, Gomes L, Ribeiro MS: Bactericidal effect of malachite green and red laser on Actinobacillus actinomycetemcomitans. J Photochem Photobiol B 2007;86:70-76.

26 Komerik N, Nakanishi H, MacRobert AJ, Henderson B, Speight P, Wilson M: In vivo killing of Porphyromonas gingivalis by toluidine blue-mediated photosensitization in an animal model. Antimicrob Agents Chemother 2003;47:932-940.

27 Sigusch BW, Pfitzner A, Albrecht V, Glockmann E: Efficacy of photodynamic therapy on inflammatory signs and two selected periodontopathogenic species in a beagle dog model. J Periodontol 2005;76:1100-1105. 
Yumoto et al.: Electromagnetic Activation of Osteoblasts

28 Yumoto H, Tominaga T, Hirao K, Kimura T, Takahashi K, Sumitomo T, Bando N, Matsuo T: Bactericidal activity and oral pathogen inactivation by electromagnetic wave irradiation. J Appl Microbiol 2012;113:181-191.

-29 Spadaro JA: Mechanical and electrical interactions in bone remodeling. Bioelectromagnetics 1997;18:193202.

30 Kim IS, Song JK, Zhang YL, Lee TH, Cho TH, Song YM, Kim do K, Kim SJ, Hwang SJ: Biphasic electric current stimulates proliferation and induces VEGF production in osteoblasts. Biochim Biophys Acta 2006;1763:907-916.

-31 Aaron RK, Boyan BD, Ciombor DM, Schwartz Z, Simon BJ: Stimulation of growth factor synthesis by electric and electromagnetic fields. Clin Orthop Relat Res 2004:30-37.

-32 Ciombor DM, Aaron RK: Influence of electromagnetic fields on endochondral bone formation. J Cell Biochem 1993;52:37-41.

-33 Zhuang H, Wang W, Seldes RM, Tahernia AD, Fan H, Brighton CT: Electrical stimulation induces the level of TGF-beta1 mRNA in osteoblastic cells by a mechanism involving calcium/calmodulin pathway. Biochem Biophys Res Commun 1997;237:225-229.

-34 Aleksic V, Aoki A, Iwasaki K, Takasaki AA, Wang CY, Abiko Y, Ishikawa I, Izumi Y: Low-level Er:YAG laser irradiation enhances osteoblast proliferation through activation of MAPK/ERK. Lasers Med Sci 2010;25:559-569.

-35 Li CF, Hughes-Fulford M: Fibroblast growth factor-2 is an immediate-early gene induced by mechanical stress in osteogenic cells. J Bone Miner Res 2006;21:946-955.

-36 Ninomiya T, Hosoya A, Nakamura H, Sano K, Nishisaka T, Ozawa H: Increase of bone volume by a nanosecond pulsed laser irradiation is caused by a decreased osteoclast number and an activated osteoblasts. Bone 2007;40:140-148.

37 Khan SN, Bostrom MP, Lane JM: Bone growth factors. Orthop Clin North Am 2000;31:375-388.

-38 Lieberman JR, Daluiski A, Einhorn TA: The role of growth factors in the repair of bone. Biology and clinical applications. J Bone Joint Surg Am 2002;84-A:1032-1044.

39 Bolander ME: Regulation of fracture repair by growth factors. Proc Soc Exp Biol Med 1992;200:165-170.

40 Villars F, Guillotin B, Amedee T, Dutoya S, Bordenave L, Bareille R, Amedee J: Effect of huvec on human osteoprogenitor cell differentiation needs heterotypic gap junction communication. Am J Physiol Cell Physiol 2002;282:C775-785.

41 Fiorelli G, Orlando C, Benvenuti S, Franceschelli F, Bianchi S, Pioli P, Tanini A, Serio M, Bartucci F, Brandi ML: Characterization, regulation, and function of specific cell membrane receptors for insulin-like growth factor I on bone endothelial cells. J Bone Miner Research 1994;9:329-337.

42 Wang DS, Miura M, Demura H, Sato K: Anabolic effects of 1,25-dihydroxyvitamin D3 on osteoblasts are enhanced by vascular endothelial growth factor produced by osteoblasts and by growth factors produced by endothelial cells. Endocrinology 1997;138:2953-2962.

43 Fredriksson L, Li H, Eriksson U: The pdgf family: Four gene products form five dimeric isoforms. Cytokine Growth Factor Rev 2004;15:197-204.

-44 Hollinger JO, Hart CE, Hirsch SN, Lynch S, Friedlaender GE: Recombinant human platelet-derived growth factor: Biology and clinical applications. J Bone Joint Surg Am 2008;90:S48-54.

45 Bouletreau PJ, Warren SM, Spector JA, Steinbrech DS, Mehrara BJ, Longaker MT: Factors in the fracture microenvironment induce primary osteoblast angiogenic cytokine production. Plast Reconstr Surg 2002;110:139-148.

46 Wrotniak M, Bielecki T, Gazdzik TS: Current opinion about using the platelet-rich gel in orthopaedics and trauma surgery. Ortop Traumatol Rehabil 2007;9:227-238.

47 Celotti F, Colciago A, Negri-Cesi P, Pravettoni A, Zaninetti R, Sacchi MC: Effect of platelet-rich plasma on migration and proliferation of SaOS-2 osteoblasts: Role of platelet-derived growth factor and transforming growth factor-beta. Wound Repair Regen 2006;14:195-202.

48 Lind M, Deleuran B, Thestrup-Pedersen K, Soballe K, Eriksen EF, Bunger C: Chemotaxis of human osteoblasts. Effects of osteotropic growth factors. APMIS 1995;103:140-146.

49 Wlodarski H, Galus R: Histological aspects of bone fracture healing. Ortop Traumatol Rehabil 2005; 7:351360 .

50 Letterio JJ, Roberts AB: Regulation of immune responses by TGF-beta. Annu Rev Immunol 1998;16:137161.

51 Bottcher RT, Niehrs C: Fibroblast growth factor signaling during early vertebrate development. Endocr Rev 2005;26:63-77. 
Yumoto et al.: Electromagnetic Activation of Osteoblasts

52 Montero A, Okada Y, Tomita M, Ito M, Tsurukami H, Nakamura T, Doetschman T, Coffin JD, Hurley MM: Disruption of the fibroblast growth factor-2 gene results in decreased bone mass and bone formation. J Clin Invest 2000;105:1085-1093.

53 Murakami S: Periodontal tissue regeneration by signaling molecule(s): What role does basic fibroblast growth factor (FGF-2) have in periodontal therapy? Periodontol 2000 2011;56:188-208.

54 Kawaguchi H, Nakamura K, Tabata Y, Ikada Y, Aoyama I, Anzai J, Nakamura T, Hiyama Y, Tamura M: Acceleration of fracture healing in nonhuman primates by fibroblast growth factor-2. J Clin Endocrinol Metab 2001;86:875-880.

55 Nakamura T, Hara Y, Tagawa M, Tamura M, Yuge T, Fukuda H, Nigi H: Recombinant human basic fibroblast growth factor accelerates fracture healing by enhancing callus remodeling in experimental dog tibial fracture. J Bone Miner Res 1998;13:942-949.

56 Nakamae A, Sunagawa T, Ishida O, Suzuki O, Yasunaga Y, Hachisuka H, Ochi M: Acceleration of surgical angiogenesis in necrotic bone with a single injection of fibroblast growth factor-2 (FGF-2). J Orthop Res 2004;22:509-513.

57 Moussad EE, Brigstock DR: Connective tissue growth factor: What's in a name? Mol Genet Metab 2000;71:276-292.

58 Luo Q, Kang Q, Si W, Jiang W, Park JK, Peng Y, Li X, Luu HH, Luo J, Montag AG, Haydon RC, He TC: Connective tissue growth factor (CTGF) is regulated by wnt and bone morphogenetic proteins signaling in osteoblast differentiation of mesenchymal stem cells. J Biol Chem 2004;279:55958-55968.

-59 Kawaki H, Kubota S, Suzuki A, Yamada T, Matsumura T, Mandai T, Yao M, Maeda T, Lyons KM, Takigawa M: Functional requirement of CCN2 for intramembranous bone formation in embryonic mice. Biochem Biophys Res Commun 2008;366:450-456.

60 Smerdel-Ramoya A, Zanotti S, Deregowski V, Canalis E: Connective tissue growth factor enhances osteoblastogenesis in vitro. J Biol Chem 2008;283:22690-22699.

61 Safadi FF, Xu J, Smock SL, Kanaan RA, Selim AH, Odgren PR, Marks SC, Jr., Owen TA, Popoff SN: Expression of connective tissue growth factor in bone: Its role in osteoblast proliferation and differentiation in vitro and bone formation in vivo. J Cell Physiol 2003;196:51-62.

62 Babic AM, Chen CC, Lau LF: Fisp12/mouse connective tissue growth factor mediates endothelial cell adhesion and migration through integrin alphavbeta3, promotes endothelial cell survival, and induces angiogenesis in vivo. Mol Cell Biol 1999;19:2958-2966.

63 Lau LF, Lam SC: The CCN family of angiogenic regulators: The integrin connection. Exp Cell Res 1999;248:44-57.

64 Nakata E, Nakanishi T, Kawai A, Asaumi K, Yamaai T, Asano M, Nishida T, Mitani S, Inoue H, Takigawa M: Expression of connective tissue growth factor/hypertrophic chondrocyte-specific gene product 24 (CTGF/ Hcs24) during fracture healing. Bone 2002;31:441-447.

65 Denhardt DT, Giachelli CM, Rittling SR: Role of osteopontin in cellular signaling and toxicant injury. Annu Rev Pharmacol Toxicol 2001;41:723-749.

66 Gerstenfeld LC: Osteopontin in skeletal tissue homeostasis: An emerging picture of the autocrine/ paracrine functions of the extracellular matrix. J Bone Miner Res 1999;14:850-855.

67 Moore MA, Gotoh Y, Rafidi K, Gerstenfeld LC: Characterization of a cDNA for chicken osteopontin: Expression during bone development, osteoblast differentiation, and tissue distribution. Biochemistry 1991;30:2501-2508.

68 Pearson G, Robinson F, Beers Gibson T, Xu BE, Karandikar M, Berman K, Cobb MH: Mitogen-activated protein (MAP) kinase pathways: Regulation and physiological functions. Endocr Rev 2001;22:153-183.

69 Robinson MJ, Cobb MH: Mitogen-activated protein kinase pathways. Curr Opin Cell Biol 1997;9:180-186.

70 Lai CF, Chaudhary L, Fausto A, Halstead LR, Ory DS, Avioli LV, Cheng SL: Erk is essential for growth, differentiation, integrin expression, and cell function in human osteoblastic cells. J Biol Chem 2001;276:14443-14450.

71 Xiao G, Gopalakrishnan R, Jiang D, Reith E, Benson MD, Franceschi RT: Bone morphogenetic proteins, extracellular matrix, and mitogen-activated protein kinase signaling pathways are required for osteoblastspecific gene expression and differentiation in MC3T3-E1 cells. J Bone Miner Res 2002;17:101-110.

-72 Johnson GL, Lapadat R: Mitogen-activated protein kinase pathways mediated by ERK, JNK, and p38 protein kinases. Science 2002;298:1911-1912.

-73 Garrington TP, Johnson GL: Organization and regulation of mitogen-activated protein kinase signaling pathways. Curr Opin Cell Biol 1999;11:211-218. 